\title{
Isolation, Absolute Configuration and Cytotoxic Activities of Alkaloids from Hippeastrum goianum (Ravenna) Meerow (Amaryllidaceae)
}

\author{
Mariacaterina Lianza, ${ }^{\#, a, b}$ Maria Helena Verdan, ${ }^{\#, b}$ Jean Paulo de Andrade, ${ }^{b, c}$ \\ Ferruccio Poli, ${ }^{a}$ Larissa C. de Almeida, ${ }^{d}$ Leticia V. Costa-Lotufo, ${ }^{d}$ Álvaro Cunha Neto, ${ }^{b}$ \\ Sarah C. C. Oliveira, ${ }^{e} J a u m e ~ B a s t i d a,{ }^{f}$ Andrea N. L. Batista, ${ }^{g}$ \\ João M. Batista Jr. ${ }^{\circledR h}$ and Warley S. Borges ${ }^{\circledR *, b}$ \\ ${ }^{a}$ Department of Pharmacy and Biotechnology, Almer Mater Studiorum, \\ University of Bologna, CP 40126, Bologna, Italy \\ ${ }^{b}$ Departamento de Química, Universidade Federal do Espírito Santo, 29075-910 Vitória-ES, Brazil \\ ${ }^{c}$ Laboratorio de Química de Productos Naturales, \\ Instituto de Química de Recursos Naturales, y Núcleo Científico Multidisciplinario, \\ Dirección de Investigación, Universidad de Talca, CP 3460000, Talca, Chile \\ ${ }^{d}$ Departamento de Farmacologia, Universidade de São Paulo, 05508-900 São Paulo-SP, Brazil \\ ${ }^{e}$ Departamento de Botânica, Universidade de Brasília, 70910-900 Brasília-DF, Brazil \\ ${ }^{f}$ Departament de Biologia, Sanitat i Medi Ambient, Facultat de Farmàcia i Ciències de l'Alimentació, \\ Universitat de Barcelona, CP 08028, Barcelona, Spain \\ ${ }^{8}$ Instituto de Química, Universidade Federal Fluminense, 24020-141 Niterói-RJ, Brazil \\ ${ }^{h}$ Instituto de Ciência e Tecnologia, Universidade Federal de São Paulo, \\ 12231-280 São José dos Campos-SP, Brazil
}

\begin{abstract}
The phytochemical study of Hippeastrum goianum led to the identification of 13 compounds by means of gas chromatography-mass spectrometry (GC-MS) and nuclear magnetic resonance (NMR). Compounds 7-demethoxy-9-O-methylhostasine (1) and 7-deoxi-trans-dihydronarciclasine (2) had their absolute configurations determined by vibrational circular dichroism (VCD). This is the first time that compound $\mathbf{1}$ is described in the Amaryllidaceae family. The cytotoxicity of all isolated compounds was tested against colorectal carcinoma (HCT 116), breast carcinoma (MCF-7), and non-tumor human retinal pigment epithelium (RPE) cell lines. The half-maximum inhibitory concentration ( $\left.\mathrm{IC}_{50}\right)$ of compound $\mathbf{2}$ against each cell line was equivalent to the positive control (doxorubicin), indicating a considerable cytotoxic activity.
\end{abstract}

Keywords: narciclasine, galasine, cytotoxic activity, absolute configuration, vibrational circular dichroism

\section{Introduction}

The genus Hippeastrum, belonging to the Amaryllidaceae family, Hippeastreae tribe, subfamily Amaryllidoideae, has about 70 species, distributed throughout Latin America, particularly in Brazil. The latest research pointed to the occurrence of about 30 Brazilian species, including 21

*e-mail: warley.borges@ufes.br

"These authors contributed equally to this study. that are considered endemic. ${ }^{1}$ Several studies ${ }^{2}$ showed a peculiar taxonomy of the genus Hippeastrum, reinforcing the significance of chemical and pharmacological studies with these plants. Bulbs from many species of the genus Hippeastrum yielded numerous alkaloids, with 64 being fully characterized. ${ }^{2}$ Considering the promising biological activities showed by these alkaloids, such as cytotoxic, ${ }^{3}$ psychopharmacological ${ }^{4}$ and acetylcholinesterase (AChE) inhibitory activities, ${ }^{5}$ this class of compounds is of remarkable importance. 
Isoquinolinic alkaloids from Amaryllidaceae plants, especially the narciclasine-type derivatives, have pronounced cytotoxic activities ${ }^{6}$ and might be helpful in the cancer therapy. Cancer is a serious disease, considered the main cause of death in the world and many products used in the cancer therapy are natural products or natural products derivatives. ${ }^{7-9}$ Therefore, it is important to search for new compounds that can be used against cancer.

This study was focused on Hippeastrum goianum (Ravenna) Meerow, an endemic species of Brazil, growing in the central-west part of the country, precisely in the Cerrado ecosystem. ${ }^{10}$ Considering that little information on the phytochemical composition of $H$. goianum is available, ${ }^{11}$ gas chromatography-mass spectrometry (GC-MS) based on qualitative and relative quantitative analysis was performed on hexane (n-Hex) and ethyl acetate (EtOAc) alkaloidenriched extracts of the bulbs from this species. Out of the thirteen compounds identified by GC-MS, five were isolated and evaluated for cytotoxic activity against colon adenocarcinoma (HCT-116), breast carcinoma (MCF-7), and non-tumor retinal pigment epithelium (RPE) cell lines. Compounds 7-demethoxy-9-O-methylhostasine (1) and 7-deoxi-trans-dihydronarciclasine (2) had their absolute configurations determined by using vibrational circular dichroism (VCD) and compound $\mathbf{1}$ is reported for the first time in Amaryllidaceae family.

\section{Experimental}

\section{General experimental procedures}

The column chromatographic separations (CC) were done using silica gel (70-90 $\mu \mathrm{m}$, Agela Technologies, Phenomenex Company, China) or Sephadex ${ }^{\circledR}$ (LH-20, GE Healthcare, USA). All Sephadex ${ }^{\circledR}$ columns were performed using methanol pro analysis (P.A.) (MeOH, LabSynth, Brazil) as mobile phase. For the acid-base extraction, the solvents sulfuric acid, ammonium hydroxide, $n$-hexane, ethyl acetate (EtOAc), and dichloromethane (DCM) of analytical grade were used (LabSynth, Diadema, Brazil). Preparative thin layer chromatography (PTLC) was performed with pre-coated aluminum plates with silica gel $\mathrm{F}_{254}$ (Macherey-Nagel ${ }^{\circledR}$, France). The plates were analyzed by exposure under ultraviolet (UV) light (254 and $366 \mathrm{~nm}$ ) and spraying with Dragendorff reagent. High-performance liquid chromatography (HPLC) purifications were done on an Agilent Chromatograph, coupled with a diode array (DAD) detector (1260 MWD), using a semipreparative column (Eclipse XDB-18, $5 \mu \mathrm{m}$ of particle size, $9.4 \times 250 \mathrm{~mm}$ ). All employed solvents were analytical grade, or HPLC grade when needed (LabSynth, Diadema,
Brazil). Gas chromatography analyses were performed on a GC-17A Shimadzu GC-MS QP 5000 operating in the electronic impact (EI) mode at $70 \mathrm{eV}$ using a DB5 MS column $(30 \mathrm{~m} \times 0.25 \mathrm{~mm} \times 0.25 \mu \mathrm{m})$. The temperature program was as follows: $100-180^{\circ} \mathrm{C}$ at $15^{\circ} \mathrm{C} \mathrm{min} \mathrm{m}^{-1}, 1 \mathrm{~min}$ hold at $180{ }^{\circ} \mathrm{C}$ and $180-300{ }^{\circ} \mathrm{C}$ at $5{ }^{\circ} \mathrm{C} \mathrm{min}{ }^{-1}$ and $10 \mathrm{~min}$ hold at $300{ }^{\circ} \mathrm{C}$. The injector temperature was $280{ }^{\circ} \mathrm{C}$. The flow rate of carrier gas (helium) was $0.8 \mathrm{~mL} \mathrm{~min}^{-1}$, and the split ratio was 1:20. The Amaryllidaceae alkaloids identified by GC-MS had their mass spectra deconvoluted using AMDIS 2.64 software (NIST) ${ }^{12}$ and retention indices (RIs) recorded using a standard $n$-hydrocarbon calibration mixture (C9-C36). Thus, their GC-MS spectra and Kovats RI were compared to those presented in our library database. This library has been regularly updated with alkaloids isolated and unequivocally identified via physical and spectroscopic methods.

The ${ }^{1} \mathrm{H},{ }^{13} \mathrm{C}$ and two-dimensional (2D) nuclear magnetic resonance (NMR) spectra were performed in a VNMRS400 spectrometer, operating at $9.4 \mathrm{~T}$, using a $5 \mu \mathrm{m}{ }^{1} \mathrm{H} / \mathrm{X} / \mathrm{D}$ BroadBand probe. Deuterated chloroform $\left(\mathrm{CDCl}_{3}\right)$, methanol $\left(\mathrm{CD}_{3} \mathrm{OD}\right)$ and dimethyl sulfoxide (DMSO- $\left.d_{6}\right)$ were used as solvent (Sigma-Aldrich, Steinheim, Germany). The nuclear Overhauser enhancement difference (NOEdiff) experiments were performed applying the one-dimensional nuclear Overhauser effect spectroscopy (1D-NOESY) pulse sequence, with the mixing time optimization for each experiment. HRESIMS (highresolution electrospray ionization mass spectrometry) was performed on 9.4 T FT-ICRMS (Solarix, Germany) by direct injection of the compound dissolved in $\mathrm{MeOH}$. Infrared (IR) and VCD spectra of $\mathbf{1}$ and $\mathbf{2}$, were recorded with a Single-PEM Chiral IR-2X FT-VCD spectrometer (BioTools, Inc, Jupiter, FL, USA) using a resolution of $4 \mathrm{~cm}^{-1}$ and a collection time of $7 \mathrm{~h}$. The optimum retardation of the $\mathrm{ZnSe}$ photoelastic modulator (PEM) was set at $1400 \mathrm{~cm}^{-1}$. Minor instrumental baseline offsets were eliminated from the final VCD spectrum by subtracting the VCD spectrum of each compound from that obtained for the solvent under identical conditions. The IR and VCD spectra were recorded in $\mathrm{BaF}_{2}$ cell with $100 \mu \mathrm{m}$ path length using DMSO- $d_{6}$ as solvent. The samples were prepared as follows: $6 \mathrm{mg}$ of compound $\mathbf{1}$ and $3 \mathrm{mg}$ of compound $\mathbf{2}$, both dissolved in $120 \mu \mathrm{L}$ of DMSO- $d_{6}$.

\section{Plant material}

Bulbs from Hippeastrum goianum (Ravenna) Meerow were harvested at the University of Brasília, Brasília, Distrito Federal, Brazil in September 2016. The material was identified by Dr Sarah Christina Caldas Oliveira and 
a voucher was deposited at the Herbarium of the Federal University of Espírito Santo (VIES 39499). Registration SisGen No. A012E5E.

\section{Extraction and isolation}

Bulbs $(2.1 \mathrm{~kg})$ were dried at $40{ }^{\circ} \mathrm{C}$ and crushed. The resulting material $(579 \mathrm{~g})$ was extracted with $\mathrm{MeOH}$ (4 times, $24 \mathrm{~h}$ each). The dried extract (148 g) was acidified with sulfuric acid (2\%) to $\mathrm{pH} 2$ and further extracted with petroleum ether $(\mathrm{PE})(3 \times 200 \mathrm{~mL})$ and ethyl acetate $($ EtOAc) $(3 \times 200 \mathrm{~mL})$. The aqueous solution was basified with ammonium hydroxide (30\%) to $\mathrm{pH} 9-10$ and then extracted with $n$-hexane $(7 \times 150 \mathrm{~mL})$ to give extract $\mathrm{C}$ $(57.3 \mathrm{mg})$, EtOAc $(20 \times 150 \mathrm{~mL})$ to produce extract $\mathrm{D}$ $(8.2 \mathrm{~g})$, from which compound 2 precipitated $(530.6 \mathrm{mg})$, and EtOAc-MeOH $(3: 1)(3 \times 150 \mathrm{~mL})$ that gave extract $\mathrm{E}$ $(9.2 \mathrm{~g})$, all of which showed positive results for alkaloids according to Dragendorff's reagent. Extracts C and D were analyzed by GC-MS. Extract D was fractionated by Sephadex ${ }^{\circledR}$ column eluted with $\mathrm{MeOH}$, resulting in 69 fractions, grouped in three main fractions. Fraction D.2 $(6.6 \mathrm{~g})$ was subjected to Sephadex ${ }^{\circledR}$ column giving 50 fractions, combined in four subfractions based on TLC profiles. Subfraction D.2.2 (732.3 mg) was submitted to a new Sephadex ${ }^{\oplus}$ column resulting in 81 fractions, grouped in five subfractions. Subfraction D.2.2.2 (517.9 mg) was fractionated by silica gel CC eluted on EtOAc containing increasing amounts of a solution with DCM and $\mathrm{MeOH}$ (1:1) until the proportion of the mixture DCM-MeOH reached $100 \%$. This resulted in 111 fractions that were grouped in five subfractions after TLC analysis. Subfraction D.2.2.2.2 (60.6 $\mathrm{mg})$ was identified as compound 1. Fraction D.2.3 $(5.7 \mathrm{~g})$ was submitted to silica gel CC first eluted with EtOAc, then gradients of DCM-MeOH $(1: 1,0 \rightarrow 100 \%)$ were added, yielding 262 fractions and combined in 11 subfractions. Subfractions D.2.3.4, D.2.3.7, D.2.3.8 and D.2.3.10 showed positive results for alkaloids (positive Dragendorff's spots). Subfraction D.2.3.4 (578.8 mg) was subjected to silica gel CC eluted with EtOAc followed by gradients of DCM-MeOH $(1: 1,0 \rightarrow 100 \%)$ providing 112 fractions, which were combined in four subfractions. Compound 1 was obtained from subfraction D.2.3.4.2 $(321.0 \mathrm{mg})$ after PTLC in $n$-hexane-DCM-EtOAc-acetone$\mathrm{MeOH}$ (3:1.5:2:1.5-5 drops of ammonium hydroxide were add into the solvent system) as elution system. Subfraction D.2.3.7 (254.8 mg) was submitted to Sephadex ${ }^{\circledR}$ column, resulting in 60 fractions grouped in nine subfractions. Subfraction D.2.3.7.5 (41.1 mg) was subjected to PTLC in $\mathrm{EtOAc}-\mathrm{CHCl}_{3}$-acetone-MeOH (5:5:3:5), resulting in the precipitation of compound $\mathbf{1 1}(9.4 \mathrm{mg})$. Subfraction
D.2.3.8 (588.2 mg) was submitted to Sephadex ${ }^{\circledR}$ column, resulting in 62 fractions grouped in five subfractions. Compound $13(4.3 \mathrm{mg})$ precipitated from subfraction D.2.3.8.2 (206.7 mg). Subfraction D.2.3.10 (267.4 mg) was subjected to Sephadex ${ }^{\circledR}$ column resulting in 60 fractions combined in four subfractions. Subfraction D.2.3.10.1 $(175.9 \mathrm{mg})$ was fractionated with CC of silica gel eluted with DCM, gradients of $\mathrm{MeOH}$ on DCM and pure $\mathrm{MeOH}$, yielding 74 fractions, grouped in four subfractions. Subfraction D.2.3.10.1.2 (16.3 mg) was submitted to HPLC fractionation employing a gradient method with $\mathrm{H}_{2} \mathrm{O}$ and $\mathrm{MeOH}$. The method $\left(7 \mathrm{~mL} \mathrm{~min}^{-1}\right)$ increased the amount of $\mathrm{MeOH}$ from 10 to $50 \%$ in $20 \mathrm{~min}$, then returned to $10 \%$ in $5 \mathrm{~min}$, and this percentage was kept for $10 \mathrm{~min}$. The first band that eluted at 3.14 min was extracted with $\mathrm{CHCl}_{3}-\mathrm{MeOH}$ (4:1) and identified as compound $\mathbf{6}(2.0 \mathrm{mg})$.

\section{Cell culture and MTT assay}

HCT-116 (colon adenorcarcinoma) cells were grown in Roswell Park Memorial Institute medium (RPMI) and MCF-7 (breast carcinoma) and RPE (non-tumor retinal pigment epithelium) cells were grown in Dulbecco's modified Eagle medium (DMEM). Both media were supplemented with $10 \%$ fetal bovine serum (FBS) and $1 \%$ antibiotics (penicillin 10,000 Units $\mathrm{mL}^{-1}$ and streptomycin $\left.10,000 \mu \mathrm{g} \mathrm{mL}{ }^{-1}\right)$. Cells were kept in an incubator with $5 \% \mathrm{CO}_{2}$ at $37{ }^{\circ} \mathrm{C}$. For 3-[4,5-dimethylthiazole-2-yl]2,5-diphenyltetrazolium bromide (MTT) assay, the cells were seeded on 96-well plates at a density of $1 \times 10^{4} \mathrm{per}$ well with $200 \mu \mathrm{L}$ culture medium. After $24 \mathrm{~h}$, compounds 1, 2, 6, 11 and $13(0.0032-50 \mu \mathrm{M})$ were added to the cultures and incubated for $72 \mathrm{~h}$. DMSO $(0.05 \%)$ was used as negative control and the antineoplastic compound doxorubicin $(0.00064-10 \mu \mathrm{M})$ was used as positive control. Three hours before the end of the experiment, culture media were replaced by fresh media containing MTT solution $\left(0.5 \mathrm{mg} \mathrm{mL}^{-1}\right)$ and incubated. The MTT solution was removed and the formazan product was solubilized in $150 \mu \mathrm{L}$ DMSO. The absorbance was obtained at $540 \mathrm{~nm}$. The $\mathrm{IC}_{50}$ values and their $95 \%$ confidence interval were calculated by sigmoidal nonlinear regression using GraphPad Prism 8.0 software. ${ }^{13}$

\section{Calculations}

Conformational searches were carried out at the molecular mechanics level of theory with the Monte Carlo algorithm employing the $\mathrm{MM}+$ force field incorporated in HyperChem 8.0.10 software package. ${ }^{14}$ Calculations were performed for the arbitrarily chosen $(1 R, 2 S, 4 \mathrm{a} R, 10 \mathrm{~b} R)-\mathbf{1}$ 
and $(2 S, 3 R, 4 S, 4 \mathrm{a} R, 10 \mathrm{~b} R)-\mathbf{2}$. Initially, 68 conformers of $(1 R, 2 S, 4 \mathrm{a} R, 10 \mathrm{~b} R)-\mathbf{1}$ with relative energy (rel E.) within $10 \mathrm{kcal} \mathrm{mol}^{-1}$ of the lowest-energy conformer were selected and further geometry optimized at the B3LYP/ PCM(DMSO)/6-31G(d) level. The five conformers with rel E. $<1.0 \mathrm{kcal} \mathrm{mol}^{-1}$ were selected for IR and VCD spectral calculations. The inclusion of explicit DMSO molecules was performed using Hyperchem software, ${ }^{14}$ on the optimized conformers of compound $\mathbf{1}$ obtained at the B3LYP/PCM(DMSO)/6-31G(d) level, which were subsequently subjected to geometry optimization and frequency calculations at the same level. As for $(2 S, 3 R, 4 S, 4 \mathrm{a} R, 10 \mathrm{~b} R)-\mathbf{2}, 12$ conformers with relative energy (rel E.) within $10 \mathrm{kcal} \mathrm{mol}^{-1}$ of the lowest-energy conformer were selected and further geometry optimized at the B3LYP/PCM(DMSO)/6-31G(d) level. The four conformers with rel E. $<1.2 \mathrm{kcal} \mathrm{mol}^{-1}$ were selected for IR and VCD spectral calculations. All density functional theory (DFT) calculations were carried out at $298 \mathrm{~K}$ in DMSO solution using the polarizable continuum model (PCM) in its integral equation formalism version (IEFPCM) incorporated in Gaussian 09 software. ${ }^{15}$ For the IR and VCD spectral simulations, the spectra were created using dipole and rotational strengths from Gaussian, which were calculated at the same level used during the geometry optimization step, and converted into molar absorptivities $\left(\mathrm{M}^{-1} \mathrm{~cm}^{-1}\right)$. Each spectrum was plotted as a sum of Lorentzian bands with half-widths at half-maximum of $6 \mathrm{~cm}^{-1}$. The calculated wavenumbers were multiplied with a scaling factor of 0.975 . The final spectra were generated according to Boltzmann weighting of the lowest-energy conformers identified and plotted using Origin 8 software. ${ }^{16}$

\section{7-Demethoxy-9-O-methylhostasine (1)}

Amorphous yellowish solid. ${ }^{1} \mathrm{H}$ and ${ }^{13} \mathrm{C}$ NMR data see Table 1 and Figures S1-S10 (Supplementary Information (SI) section). HRESIMS $\mathrm{m} / z$, calcd. for $\mathrm{C}_{18} \mathrm{H}_{22} \mathrm{NO}_{6}{ }^{+}$ $[\mathrm{M}+\mathrm{H}]^{+}:$348.14417, found: 348.14458; calcd. for $\mathrm{C}_{36} \mathrm{H}_{43} \mathrm{~N}_{2} \mathrm{O}_{12}{ }^{+}[2 \mathrm{M}+\mathrm{H}]^{+}:$695.28105, found: 695.28416; calcd. for $\mathrm{C}_{54} \mathrm{H}_{63} \mathrm{~N}_{3} \mathrm{NaO}_{18}{ }^{+}[3 \mathrm{M}+\mathrm{Na}]^{+}: 1064.39989$, found: 1064.40808 ; calcd. for $\mathrm{C}_{72} \mathrm{H}_{84} \mathrm{~N}_{4} \mathrm{NaO}_{24}{ }^{+}[4 \mathrm{M}+\mathrm{Na}]^{+}$: 1411.53677, found: 1411.55830 (Figure S11, SI section).

\section{7-Deoxi-trans-dihydronarciclasine (2)}

Amorphous white solid. ${ }^{1} \mathrm{H}$ and ${ }^{13} \mathrm{C}$ NMR data see Table 2 and Figures S13-S19 (SI section). HRESIMS $m / z$, calcd. for $\mathrm{C}_{14} \mathrm{H}_{16} \mathrm{NO}_{6}{ }^{+}[\mathrm{M}+\mathrm{H}]^{+}: 294.09722$, found: 294.09717; calcd. for $\mathrm{C}_{28} \mathrm{H}_{31} \mathrm{~N}_{2} \mathrm{O}_{12}{ }^{+}[2 \mathrm{M}+\mathrm{H}]^{+}$: 587.18715,

Table 1. NMR data for compound 1 in $400 \mathrm{MHz}$ and comparison with the literature (400 MHz, MeOD) $)^{17}$

\begin{tabular}{|c|c|c|c|c|c|c|c|c|c|}
\hline Position & $\delta_{\mathrm{H}}$, mult. $(J / \mathrm{Hz})^{\mathrm{a}}$ & $\delta_{\mathrm{C}}^{\mathrm{a}, \mathrm{b}}$ & $\operatorname{COSY}^{\mathrm{a}}$ & $\mathrm{HMBC}^{\mathrm{a}}$ & $\delta_{\mathrm{H}}$, mult. $(J / \mathrm{Hz})^{\mathrm{c}}$ & $\delta_{\mathrm{C}}{ }^{\mathrm{c}}$ & $\mathrm{HMBC}^{\mathrm{c}}$ & $\delta_{\mathrm{H}}$, mult. $(J / \mathrm{Hz})^{17}$ & $\delta_{\mathrm{C}}{ }^{17}$ \\
\hline 1 & $3.82 \mathrm{brs}$ & 76.3 & N.O. & $10 \mathrm{~b}$ & 3.60 brt (1.2) & 78.1 & N.O. & $3.60 \mathrm{~s}$ & 78.1 \\
\hline 2 & $4.13 \mathrm{brs}$ & 70.9 & 3 & N.O. & $4.09-4.13 \mathrm{~m}$ & 72.4 & N.O. & $4.10 \mathrm{~s}$ & 72.4 \\
\hline 3 & $5.70 \mathrm{brs}$ & 118.2 & $2,4 a, 11$ & N.O. & $5.67-5.71 \mathrm{~m}$ & 120.2 & N.O. & 5.70 brs & 120.3 \\
\hline 4 & - & 141.7 & - & - & - & 141.7 & - & & 141.6 \\
\hline $4 a$ & 3.40 brs & 65.5 & 3,11 & N.O. & $3.47-3.50 \mathrm{~m}$ & 67.1 & 4, NMe & $3.49 \mathrm{~s}$ & 67.1 \\
\hline 6 & - & N.O. & - & - & - & 171.5 & - & & 171.4 \\
\hline $6 a$ & - & 117.4 & - & - & - & 118.7 & - & & 118.8 \\
\hline 7 & $7.28 \mathrm{~s}$ & 106.0 & N.O. & $9,10 \mathrm{a}$ & $7.36 \mathrm{~s}$ & 107.5 & $6,9,10 \mathrm{a}$ & $7.34 \mathrm{~s}$ & 107.0 \\
\hline 8 & - & 150.9 & - & - & - & 152.7 & - & & 152.7 \\
\hline 9 & - & 154.4 & - & - & - & 156.3 & - & & 156.3 \\
\hline 10 & $7.23 \mathrm{~s}$ & 105.5 & N.O. & $6 a, 8,9$ & $7.35 \mathrm{~s}$ & 107.1 & $6 \mathrm{a}, 8$ & $7.35 \mathrm{~s}$ & 107.5 \\
\hline $10 \mathrm{a}$ & - & 145.6 & - & - & - & 147.2 & - & & 147.1 \\
\hline $10 \mathrm{~b}$ & - & 83.7 & - & - & - & 85.1 & - & & 85.0 \\
\hline $11 \alpha / \beta$ & $2.47-2.55 \mathrm{~m}$ & 27.7 & $3,12 \alpha, 12 \beta$ & 4 & $2.41-2.62 \mathrm{~m}$ & 28.8 & N.O. & $2.58 \mathrm{~m}-2.48 \mathrm{~m}$ & 28.7 \\
\hline $12 \alpha$ & $3.10 \mathrm{ddd}(9.6,6.0,4.0)$ & 55.2 & $11,12 \beta$ & N.O. & $3.04 \mathrm{ddd}(9.6,8.0,2.4)$ & 56.7 & 4 & $3.05 \mathrm{~m}$ & 56.8 \\
\hline $12 \beta$ & 2.27 q (9.6) & & $11,12 \alpha$ & N.O. & $2.33 \mathrm{q}(9.6)$ & & $\mathrm{NMe}$ & $2.36 \mathrm{dd}(18.4,9.2)$ & \\
\hline $8-\mathrm{OCH}_{3}$ & $3.92 \mathrm{~s}$ & 56.1 & - & 8 & $3.92 \mathrm{~s}$ & 56.7 & 8 & $3.92 \mathrm{~s}$ & 56.7 \\
\hline $9-\mathrm{OCH}_{3}$ & $3.97 \mathrm{~s}$ & 56.3 & - & 9 & $3.97 \mathrm{~s}$ & 56.9 & 9 & $3.96 \mathrm{~s}$ & 56.9 \\
\hline $\mathrm{N}-\mathrm{CH}_{3}$ & $1.61 \mathrm{~s}$ & 43.2 & - & $4 a, 12$ & $1.65 \mathrm{~s}$ & 43.4 & $4 a, 12$ & $1.66 \mathrm{~s}$ & 43.4 \\
\hline
\end{tabular}

${ }^{\mathrm{a}} \mathrm{CDCl}_{3}$; ${ }^{\text {b }}$ Shifts were obtained using the correlations observed in the HSQC and HMBC spectra; ${ }^{\mathrm{c}} \mathrm{MeOD} . \delta_{\mathrm{H}}$ : chemical shift of hydrogen; mult.: multiplicity of hydrogen; $J$ : coupling constants; $\delta_{\mathrm{C}}$ : chemical shift of carbon-13; HMBC: heteronuclear multiple bond correlation; N.O.: not observed. 
Table 2. NMR data for compound $2\left(400 \mathrm{MHz}, \mathrm{DMSO}-d_{6}\right)$ and comparison with literature ${ }^{18,19}$

\begin{tabular}{|c|c|c|c|c|c|c|c|}
\hline Position & $\delta_{\mathrm{H}}$, mult. $(\mathrm{J} / \mathrm{Hz})$ & $\delta_{\mathrm{C}}$ & COSY & HMBC & $\begin{array}{c}\delta_{\mathrm{H}}, \text { mult. } \\
(J / \mathrm{Hz})^{19} \\
\left(300 \mathrm{MHz}, \mathrm{DMSO}-d_{6}\right)\end{array}$ & $\begin{array}{c}\delta_{\mathrm{H}}{ }^{18}(500 \mathrm{MHz} \\
\left.\text { DMSO- } d_{6}\right)\end{array}$ & $\begin{array}{c}\delta_{\mathrm{C}}{ }^{18}(125 \mathrm{MHz} \\
\left.\text { DMSO- } d_{6}\right)\end{array}$ \\
\hline $1 \alpha$ & $2.14 \mathrm{dt}(13.2,3.4)$ & 28.4 & $1 \beta, 2,3,10,10 \mathrm{~b}$ & 2,3 & $1.59 \mathrm{dt}(13.4,2.3)$ & $2.14 \mathrm{dt}$ & 28.2 \\
\hline $1 \beta$ & $1.64 \operatorname{td}(13.2,2.4)$ & & $1 \alpha, 2,10 \mathrm{~b}$ & $10 \mathrm{~b}$ & 2.12 brd (13.3) & $1.65 \mathrm{td}$ & \\
\hline 2 & $3.89 \mathrm{~s}$ & 68.7 & $1 \alpha, 1 \beta, 3,2-\mathrm{OH}$ & $4,10 \mathrm{~b}$ & $3.84 \mathrm{~s}$ & $3.70 \mathrm{~s}$ & 69.6 \\
\hline 3 & 3.72 brs & 71.7 & $1 \alpha, 2,3-\mathrm{OH}, 4$ & $1,4 \mathrm{a}$ & $3.68 \mathrm{brs}$ & $3.87 \mathrm{~s}$ & 68.5 \\
\hline 4 & 3.72 brs & 69.8 & $3,4 a, 4-\mathrm{OH}$ & $4 a$ & $3.68 \mathrm{brs}$ & $3.70 \mathrm{~s}$ & 71.6 \\
\hline $4 a$ & $3.31 \mathrm{dd}(12.4,9.6)$ & 55.2 & $4,10 \mathrm{~b}$ & 4 & $3.23 \mathrm{~m}$ & $3.31 \mathrm{~s}$ & 55.0 \\
\hline 6 & - & 164.4 & - & - & - & - & 164.2 \\
\hline $6 a$ & - & 123.3 & - & - & - & - & 123.2 \\
\hline 7 & $7.30 \mathrm{~s}$ & 107.0 & 10 & $6,9,10 \mathrm{a}$ & $7.30 \mathrm{~s}$ & $7.29 \mathrm{~s}$ & 106.8 \\
\hline 8 & - & 146.0 & - & - & - & - & 145.8 \\
\hline 9 & - & 150.7 & - & - & - & - & 150.5 \\
\hline 10 & $6.92 \mathrm{~s}$ & 104.4 & $1 \alpha, 7,10 \mathrm{~b}$ & $7,8,9,10 \mathrm{~b}$ & $6.89 \mathrm{~s}$ & $6.92 \mathrm{~s}$ & 104.2 \\
\hline $10 \mathrm{a}$ & - & 138.1 & - & - & - & - & 137.9 \\
\hline $10 \mathrm{~b}$ & $2.88 \operatorname{td}(12.4,3.6)$ & 34.3 & $1 \alpha, 1 \beta, 4 \mathrm{a}, 10$ & $4 a, 10 a$ & $2.84 \mathrm{dt}(12.8,3.4)$ & $2.90 \mathrm{td}$ & 34.2 \\
\hline $2-\mathrm{OH}$ & $5.02 \mathrm{~s}$ & - & 2 & - & $4.91 \mathrm{~s}$ & $4.96 \mathrm{~s}$ & - \\
\hline $3-\mathrm{OH}$ & $4.84 \mathrm{~s}$ & - & 3 & - & $4.74 \mathrm{~s}$ & $4.92 \mathrm{~s}$ & - \\
\hline $4-\mathrm{OH}$ & $4.96 \mathrm{~s}$ & - & 4 & - & $4.91 \mathrm{~s}$ & $4.80 \mathrm{~s}$ & - \\
\hline $5-\mathrm{NH}$ & $6.93 \mathrm{~s}$ & - & - & $4,4 a, 6,6 a$ & $6.89 \mathrm{~s}$ & $6.92 \mathrm{~s}$ & - \\
\hline $\mathrm{OCH}_{2} \mathrm{O}$ & $6.06 \mathrm{~s}$ & 101.7 & - & 8,9 & $6.03 \mathrm{~s}$ & $6.06 \mathrm{~s}$ & 101.5 \\
\hline
\end{tabular}

$\delta_{\mathrm{H}}$ : chemical shift of hydrogen; mult.: multiplicity of hydrogen; $J$ : coupling constants; $\delta_{\mathrm{C}}$ : chemical shift of carbon-13; COSY: homonuclear correlation spectroscopy; HMBC: heteronuclear multiple bond correlation.

found: 587.18702; calcd. for $\mathrm{C}_{28} \mathrm{H}_{30} \mathrm{~N}_{2} \mathrm{NaO}_{12}{ }^{+}[2 \mathrm{M}+\mathrm{Na}]^{+}$: 609.16910, found: 609.16907 (Figure S20, SI section).

\section{Results and Discussion}

\section{GC-MS analyses}

The alkaloids identified from the bulbs of $H$. goianum through GC-MS analysis are shown in Table 3 and Figure 1. It is not common to observe a high content of primary metabolites in an alkaloid-enriched extract obtained by acid-base extraction, however, the $n$-hexane extract was composed of approximately $70 \%$ of hexadecanoic, octadecenoic and octadecadienoic acid derivatives. It is well-documented that the GC-MS method applied herein for Amaryllidoideae plant matrices detects primary metabolites in short retention time (data not shown).$^{20}$ Regarding the Amaryllidaceae alkaloids detected by GC-MS, galanthamine, crinane, lycorine and homolycorine-type series have been determined in bulbs of the species (Table 3). The hostasine derivative 7-demethoxy-9-O-methylhostasine (1) was the main component in the EtOAc fraction (43.7\%) followed by 9-O-demethyllycoramine (6-20.9\%), lycorine (11-14.7\%) and pseudolycorine (13-8.0\%). The outstanding structural difference between a galasine-type and a homolycorinetype derivative is the presence of a five-member lactone in the former rather than a six-membered one in the latter, ${ }^{21}$ even though the pyrrolidine moieties in both skeleton series are essentially the same. Actually, it has been noticed parallels between the electronic impact-mass fragmentation of $\mathbf{1}$ and that observed for the typical homolycorine-type skeleton. ${ }^{22}$ The low abundance of the molecular ion and the base peak at $\mathrm{m} / \mathrm{z}, 125$ in $\mathbf{1}$ were also detected in the electronic impact-mass fragmentation of the 2-hydroxy substituted homolycorine-type derivative hippeastrine. ${ }^{23}$ The fragmentation route of homolycorine-type alkaloids under electronic impact (EI) ionization method is well established and is dominated by the retro-Diels-Alder reaction in the hexahydroindole ring, which leads to the cleavage of the labile bonds and generates a base peak fragment representative of the pyrrolidine ring moiety $(\mathrm{m} / \mathrm{z}, 109)$, along with any substituent at C-2.21-23 Thus, as in 2-hydroxyhomolycorine-type derivatives, the $\mathrm{m} / \mathrm{z}, 125$ 
in $\mathbf{1}$ is consistent with the pyrrolidine ring moiety along with the hydroxyl substituent at C-2. Further evaluations under EI ionization source of galasine-type compounds are needed to confirm their fragmentation mode in EI mass spectrometry. The galasine-type skeleton was found for the first time in Galanthus genus in $1995,{ }^{24}$ and only recently was characterized in the species Hosta plantaginea, a representative of the Asparagaceae family.

The alkaloids 8-O-demethylhomolycorine (12) and sanguinine (4) were also detected as minor components in addition to some undefined compounds, which were determined as homolycorine representatives due to the base peaks both at $m / z 125$ and 109 . Regarding the $n$-hexane extract, similarly to what was mentioned above, the alkaloid relative content observed by GC-MS was remarkably smaller than the percentage of primary metabolites. In this fraction, the two main compounds detected by GC-MS were undefined alkaloids corresponding to 11.3 and $8.3 \%$ of the TIC. These two compounds along with the other undefined alkaloids $(2.0 \%)$ have demonstrated electronic impactmass fragmentation typical to Amaryllidaceae alkaloids, even though the use of fragmentation patterns based solely on EI-MS technique is not enough for any speculation about the skeleton-type. The small relative percentage of these undefined compounds and the low mass of extract in $n$-hexane $(57.3 \mathrm{mg})$ were evident limitations for their purification and characterization. Lycorine derivatives, such as anhydrolycorine (8-2.5\%) and dihydro-1-acetyllycorine (10-0.9\%), along with the aulicine $(\mathbf{9}-2.1 \%)$ showed low relative percentage and galanthamine $(\mathbf{3})$ along with vittatine/ crinine (7/7a) were detected as traces (less than $0.5 \%$ ).

\section{NMR approaches}

In the course of the fractionation procedure, the hostasine derivative 7-demethoxy-9-O-methylhostasine (1), the narciclasine derivative 7-deoxi-trans-dihydronarciclasine (2), 9-O-demethyllycoramine (6), lycorine (11) and pseudolycorine (13) were purified from the bulbs of H. goianum. Additionally, seven compounds were identified by means of GC-MS approaches. The chemical structures of the 13 identified compounds are shown in Figure 2.

Compound $\mathbf{1}$ was isolated as an amorphous yellowish solid with molecular formula determined by HRESIMS data, displaying a $m / z 348.14458$ peak consistent with the $[\mathrm{M}+\mathrm{H}]^{+}$ion for the molecular formula $\mathrm{C}_{18} \mathrm{H}_{22} \mathrm{NO}_{6}$, with theoretical $\mathrm{m} / \mathrm{z}$ 348.14417. It is consistent with nine indices of hydrogen deficiency. The NMR data for compound $\mathbf{1}$ were very similar to those of 8-demethoxy-10-O-methylhostasine, ${ }^{17}$ which is also named as 7-demethoxy-9-O-methylhostasine, according to the numbering proposed by Ghosal et al. ${ }^{25}$ The downfield region of the ${ }^{1} \mathrm{H}$ NMR of compound $\mathbf{1}$ showed two para aryl hydrogens at $\delta_{\mathrm{H}} 7.36(\mathrm{~s}, \mathrm{H}-7)$ and at $\delta_{\mathrm{H}} 7.35(\mathrm{~s}, \mathrm{H}-10)$ along with an olefinic hydrogen at $\delta_{\mathrm{H}} 5.67-5.71(\mathrm{~m}, \mathrm{H}-3)$ and two resonances at $\delta_{\mathrm{H}} 3.60(\mathrm{brt}, 1.2 \mathrm{~Hz}, \mathrm{H}-1)$ and at $\delta_{\mathrm{H}} 4.09-4.13$ $(\mathrm{m}, \mathrm{H}-2)$, which were consistent with the oxymethinic hydrogens $\mathrm{H}-1$ and $\mathrm{H}-2$, respectively. The two aromatic methoxyl groups were suggested by the chemical shift at $\delta_{\mathrm{H}} 3.92(\mathrm{~s})$ and at $\delta_{\mathrm{H}} 3.97(\mathrm{~s})(3 \mathrm{H}$ both) and confirmed through HMBC experiment as 8-OMe and 9-OMe groups (Table 1), respectively. The $N$-methyl group was assigned as a singlet at $\delta_{\mathrm{H}} 1.65$, in agreement to its homologous in 8-demethoxy-10-O-methylhostasine. ${ }^{17}$ Striking differences were observed in the splitting pattern of the methylene positions of the pyrrolidine ring, in comparison to the NMR data of 8-demethoxy-10-O-methylhostasine. ${ }^{17}$ As observed in others homolycorine derivatives, the H-12 $\alpha$ was split into a ddd with the geminal coupling constant $J_{12 \alpha, 12 \beta}=9.6 \mathrm{~Hz}$, which is in agreement with other homolycorine-and lycorine-type series, the latter of which is biogenetically related to homolycorines. ${ }^{26,27}$ In this attempt,
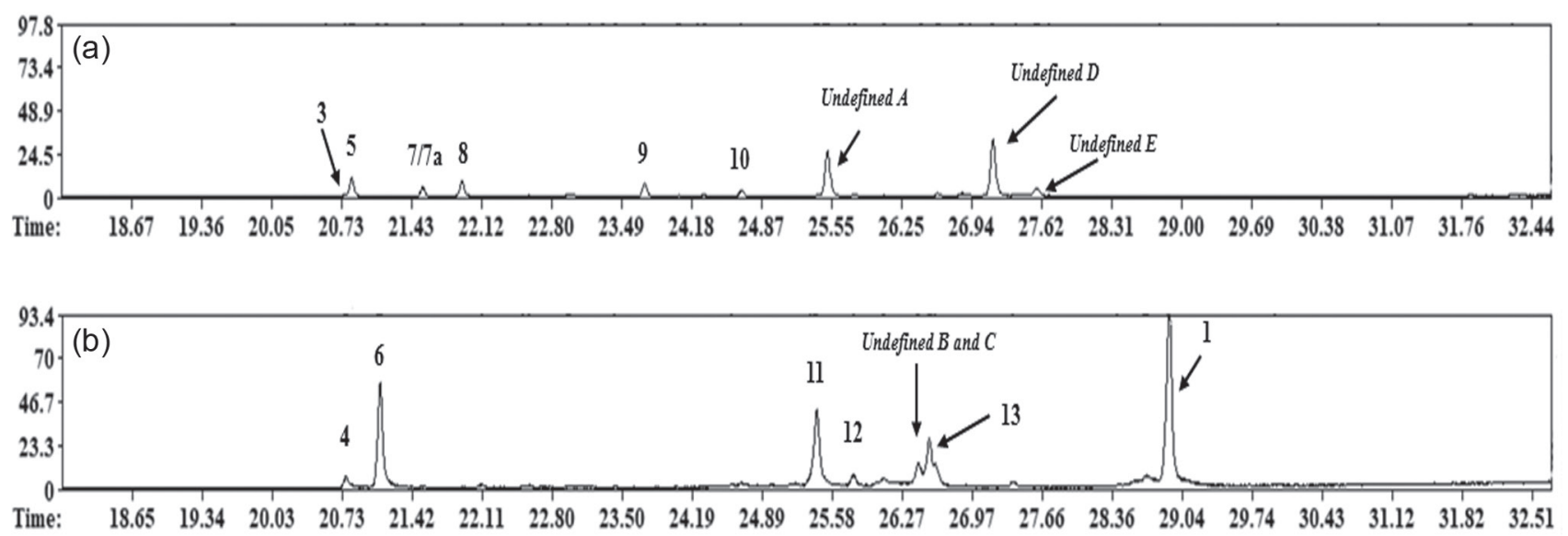

Figure 1. GC-MS spectra of the fractions (a) $n$-hexane and (b) ethyl acetate, obtained from bulbs of Hippeastrum goianum. 
Table 3. GC-MS data of bulbs of H. goianum. Values are expressed as a relative percentage of total ion current (TIC)

\begin{tabular}{|c|c|c|c|c|c|}
\hline \multirow{2}{*}{ Alkaloid } & \multirow{2}{*}{ RI } & \multicolumn{2}{|c|}{ Bulb extract } & \multirow{2}{*}{$\mathrm{M}^{+}$} & \multirow{2}{*}{ MS } \\
\hline & & $n$-Hex / \% & EtOAc / \% & & \\
\hline Galanthamine (3) & 2394 & $\operatorname{tr}$ & - & $287(83)$ & $\begin{array}{c}286(100), 270(13), 244(24), 230(12), 216(33) \\
174(27), 115(12)\end{array}$ \\
\hline Sanguinine (4) & 2403 & - & 1.0 & $273(100)$ & $\begin{array}{c}\text { 272(79), 256(18), } 216(18), 202(37), 160(44), \\
115(25)\end{array}$ \\
\hline Lycoramine (5) & 2410 & 2.6 & - & $289(62)$ & $\begin{array}{c}288(100), 232(8), 202(14), 187(14), 159(9) \\
115(19)\end{array}$ \\
\hline 9-O-Demethyllycoramine (6) & 2463 & - & 20.9 & $275(55)$ & $\begin{array}{c}274(100), 174(10), 173(14), 145(10), 131(11), \\
115(14), 44(35)\end{array}$ \\
\hline Vitatine $(\mathbf{7})$, crinine $(\mathbf{7 a})^{\mathrm{a}}$ & 2470 & $\operatorname{tr}$ & - & $271(100)$ & $\begin{array}{c}228(25), 199(95), 187(85), 173(28), 128(32), \\
115(33), 56(22)\end{array}$ \\
\hline Anhydrolycorine (8) & 2501 & 2.5 & - & 251(43) & $\begin{array}{c}250(100), 192(13), 191(11), 165(4), 164(3) \\
139(2), 124(7)\end{array}$ \\
\hline Aulicine (9) & 2656 & 2.1 & - & $319(100)$ & $\begin{array}{c}304(19), 288(37), 246(18), 233(73), 218(19), \\
206(26), 163(7)\end{array}$ \\
\hline Dihydro-1-acetyllycorine (10) & 2737 & 0.9 & - & $331(41)$ & $\begin{array}{c}330(100), 270(28), 254(30), 226(10), 147(12), \\
119(7), 89(5)\end{array}$ \\
\hline Lycorine (11) & 2746 & - & 14.7 & $287(31)$ & $\begin{array}{c}286(19), 268(24), 250(15), 227(79), 226(100), \\
211(7), 147(15)\end{array}$ \\
\hline Undefined A & 2810 & 8.3 & - & $349(27)$ & $\begin{array}{c}318(19), 276(27), 248(100), 167(9), 142(17), \\
96(25), 55(9)\end{array}$ \\
\hline 8-O-Demethylhomolycorine (12) & 2833 & - & 1.7 & $301(<1)$ & $\begin{array}{c}\text { 195(0.5), 164(2), 109(100), 108(25), 94(3), } \\
82(3)\end{array}$ \\
\hline $\begin{array}{l}\text { Undefined B (homolycorine-type 2-hydroxy } \\
\text { substituted derivative) }\end{array}$ & 2887 & - & 2.4 & nd & $\begin{array}{c}\text { 181(14), 138(19), 125(100), 124(9), 111(5), } \\
96(57), 95(8)\end{array}$ \\
\hline Undefined C (homolycorine-type derivative) & 2888 & - & 1.1 & nd & $\begin{array}{c}\text { 194(5), 163(3), 109(100), 108(18), 92(3), } \\
66(4), 58(4)\end{array}$ \\
\hline Pseudolycorine (13) & 2823 & - & 8.0 & $289(28)$ & $\begin{array}{c}270(19), 252(15), 228(100), 214(9), 147(16), \\
111(18), 82(11)\end{array}$ \\
\hline Undefined D & 2948 & 11.3 & - & $373(47)$ & $\begin{array}{c}372(100), 314(53), 272(45), 254(87), 212(14), \\
147(26), 119(11)\end{array}$ \\
\hline Undefined E & 2985 & 2.0 & - & $331(40)$ & $\begin{array}{c}330(100), 270(71), 254(22), 212(18), 147(36), \\
91(23), 77(15)\end{array}$ \\
\hline 7-Demethoxy-9- $O$-methylhostasine (1) & 3057 & - & 43.7 & nd & $\begin{array}{c}125(100), 124(8), 96(35), 81(3), 77(2), 67(2), \\
53(3)\end{array}$ \\
\hline
\end{tabular}

aThe known compounds $\mathbf{7}$ and $\mathbf{7} \mathbf{a}^{21}$ cannot be defined only by means of GC-MS. Compound $\mathbf{2}$ cannot be analyzed by GC-MS technique. RI: Kovats retention indices; $\mathrm{M}^{+}$: molecular ion; MS: MS fragments of the compounds by electron impact; nd: not detected; tr: traces.

the complete and correct assignment for compound $\mathbf{1}$ is suggested at Table 1 and confirmed it as 7-demethoxy9-O-methylhostasine. This is the first time that a hostasine derivative is isolated from a species of Amaryllidaceae. Based on the relative configuration determined from NMR data, the absolute configuration of compound $\mathbf{1}$ was unambiguously assigned by comparison of experimental and calculated VCD spectra. The correlation between observed and theoretical data obtained at the B3LYP/PCM(DMSO)/6-31G(d) level (Figure S12, SI section) led to the assignment of compound 1 as $1 R, 2 S, 4 \mathrm{a} R, 10 \mathrm{~b} R$. It is noteworthy that the best agreement with experimental data was observed after the inclusion of explicit DMSO solvation during the DFT simulation..$^{28}$
This compound was previously isolated only from Hosta plantaginea a species from the family Asparagaceae. ${ }^{17}$ This is the first report of 7-demethoxy-9-O-methylhostasine in the Amaryllidoideae subfamily.

Compound $\mathbf{2}$ had its molecular formula determined by the HRESIMS signal of $m / z 294.09717$, consistent with the $[\mathrm{M}+\mathrm{H}]^{+}$ion for the molecular formula $\mathrm{C}_{14} \mathrm{H}_{16} \mathrm{NO}_{6}$, with theoretical $\mathrm{m} / z$ 294.09722. Its ${ }^{1} \mathrm{H}$ NMR spectrum showed signals due to aromatic hydrogens at $\delta_{\mathrm{H}} 7.30(\mathrm{~s}, \mathrm{H}-7)$ and $\delta_{\mathrm{H}} 6.92(\mathrm{~s}, \mathrm{H}-10)$, a NH hydrogen at $\delta_{\mathrm{H}} 6.93$ (s, NH-5), three hydroxyl groups at $\delta_{\mathrm{H}} 5.02(\mathrm{~s}, 2-\mathrm{OH})$; at $\delta_{\mathrm{H}} 4.96$ (s, $4-\mathrm{OH})$ and at $\delta_{\mathrm{H}} 4.84(\mathrm{~s}, 3-\mathrm{OH})$; and two hydrogens with a trans relationship at $\delta_{\mathrm{H}} 2.88(\mathrm{td}, 12.4,3.6 \mathrm{~Hz}, \mathrm{H}-10 \mathrm{~b})$ 

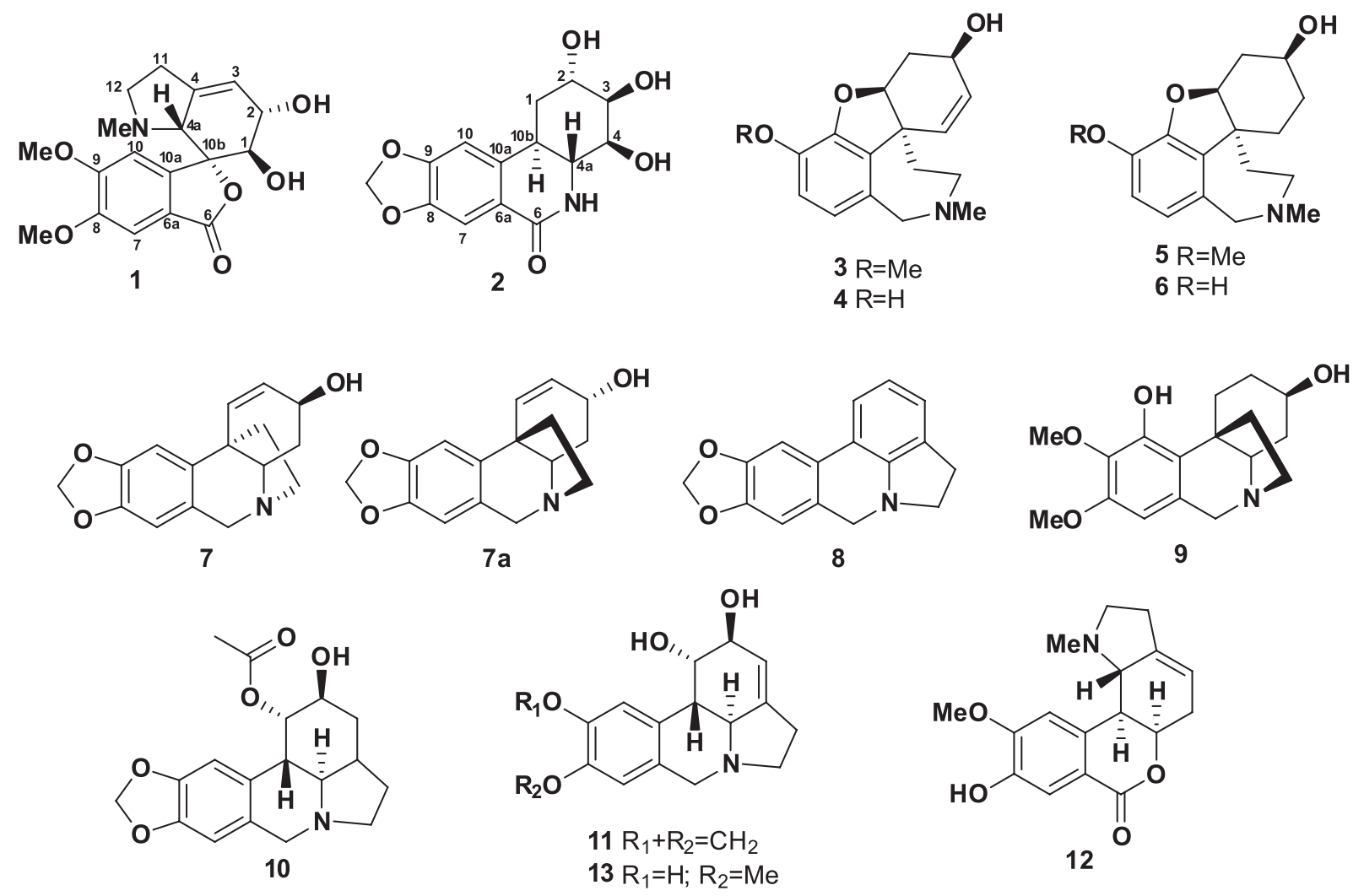

Figure 2. Chemical structures of the isolated and identified compounds in Hippeastrum goianum.

and at $\delta_{\mathrm{H}} 3.31(\mathrm{dd}, 12.4,9.6 \mathrm{~Hz}, \mathrm{H}-4 \mathrm{a})$, which indicates a 1,10b-dihydronarciclasine derivative. According to the ${ }^{13} \mathrm{C}$ NMR spectrum, there are fourteen carbons, being one of them assigned to an acyl group at $\delta_{\mathrm{C}} 164.4$, six aromatic carbons $\left(\delta_{\mathrm{C}} 104.4,107.0,123.3,138.1,146.0,150.7\right)$, one methylenedioxide carbon $\left(\delta_{\mathrm{C}} 101.7\right)$, five methine carbons $\left(\delta_{\mathrm{C}} 34.3,55.2,68.7,69.8,71.7\right)$ and one methylene carbon $\left(\delta_{\mathrm{C}} 28.4\right)$. Analysis of the COSY spectrum showed that $\mathrm{H}-10 \mathrm{~b}$ has correlation with $\mathrm{H}-1 \beta$ resonant at $\delta_{\mathrm{H}} 1.64, \mathrm{H}-1 \alpha$ $\left(\delta_{\mathrm{H}} 2.14\right), \mathrm{H}-4 \mathrm{a}\left(\delta_{\mathrm{H}} 3.31\right)$, and $\mathrm{H}-10$ resonant at $\delta_{\mathrm{H}} 6.92$, while $\mathrm{H}-2$ at $\delta_{\mathrm{H}} 3.89$ displayed correlation with $\mathrm{H}-1 \beta\left(\delta_{\mathrm{H}} 1.64\right)$, $\mathrm{H}-1 \alpha\left(\delta_{\mathrm{H}} 2.14\right), \mathrm{H}-3\left(\delta_{\mathrm{H}} 3.72\right)$ and $2-\mathrm{OH}\left(\delta_{\mathrm{H}} 5.02\right)$. These data were consistent with the structure of 7-deoxi-transdihydronarciclasine (Figure 2, Table 3). COSY, NOE experiments and $J$ values, allowed us to describe the relative stereochemistry of the stereogenic carbons. Irradiation of $\mathrm{H}-1 \beta\left(\delta_{\mathrm{H}} 1.64\right)$ resulted in NOE with $\mathrm{H}-1 \alpha\left(\delta_{\mathrm{H}} 2.14\right), \mathrm{H}-4 \mathrm{a}$ $\left(\delta_{\mathrm{H}} 3.31\right), \mathrm{H}-2\left(\delta_{\mathrm{H}} 3.89\right)$, and $\mathrm{H}-10\left(\delta_{\mathrm{H}} 6.92\right)$. When $\mathrm{H}-1 \alpha$ $\left(\delta_{\mathrm{H}} 2.14\right)$ was irradiated, NOE was observed with $\mathrm{H}-1 \beta$ $\left(\delta_{\mathrm{H}} 1.64\right), \mathrm{H}-10 \mathrm{~b}\left(\delta_{\mathrm{H}} 2.88\right), \mathrm{H}-2\left(\delta_{\mathrm{H}} 3.89\right)$, and $\mathrm{H}-10\left(\delta_{\mathrm{H}} 6.92\right)$. Additionally, $\mathrm{H}-10 \mathrm{~b}\left(\delta_{\mathrm{H}} 2.88\right)$ was irradiated showing NOE with $\mathrm{H}-1 \alpha\left(\delta_{\mathrm{H}} 2.14\right), \mathrm{H}-4\left(\delta_{\mathrm{H}} 3.72\right)$, and $\mathrm{H}-10\left(\delta_{\mathrm{H}} 6.92\right)$. The proposed relative stereochemistry is in accordance with the literature ${ }^{18}$ where $\mathrm{H}-1 \beta$ has spatial interaction with its geminal hydrogen $\mathrm{H}-1 \alpha$, as well as $\mathrm{H}-4 \mathrm{a}$ and $\mathrm{H}-2$. The hydrogen $\mathrm{H}-2$ is in gauche conformation between $\mathrm{H}-1 \alpha$ and $\mathrm{H}-1 \beta$ and its spatial correlation would be observed for both irradiations on $\mathrm{H}-1$. The relative configurations of $\mathrm{H}-2$ and H-4 are corroborated by NOE experiments since only the irradiation on $\mathrm{H}-10 \mathrm{~b}\left(\delta_{\mathrm{H}} 2.88\right)$ resulted in correlation with the oxymethinic hydrogen $\mathrm{H}-4$. The $1 \mathrm{D}$ (one-dimension)NOE correlation of the irradiated $\mathrm{H}-1 \beta, \mathrm{H}-1 \alpha$, and $\mathrm{H}-10 \mathrm{~b}$ is depicted in Figure 3.

The mono- and bi-dimensional NMR experiments (1D/2D NMR) were essential for the assignment of the relative configuration of $\mathbf{2}$, even though the overlapped H-3 and H-4 resonances along with the absence of resolved NOE correlation in the case of $\mathrm{H}-3$ did not assure the orientation of the 3-hydroxyl group. To confirm the absolute stereochemistry of 2, VCD analyses were performed. The comparison of experimental and calculated IR and VCD data at the B3LYP/PCM(DMSO)/6-31G(d) led to the assignment of its absolute configuration as $2 S, 3 R, 4 S, 4 \mathrm{a} R, 10 \mathrm{~b} R$ (Figure $\mathrm{S} 21$, SI section). In this case, simulations of implicit solvation using the polarizable continuum model (PCM) were enough for an accurate reproduction of the experimental spectra. This compound was first isolated from species of Hymenocallis genus ${ }^{19}$ and more recently from Scadoxus pseudocaulus, besides other species from the Amaryllidaceae family. ${ }^{29}$ 


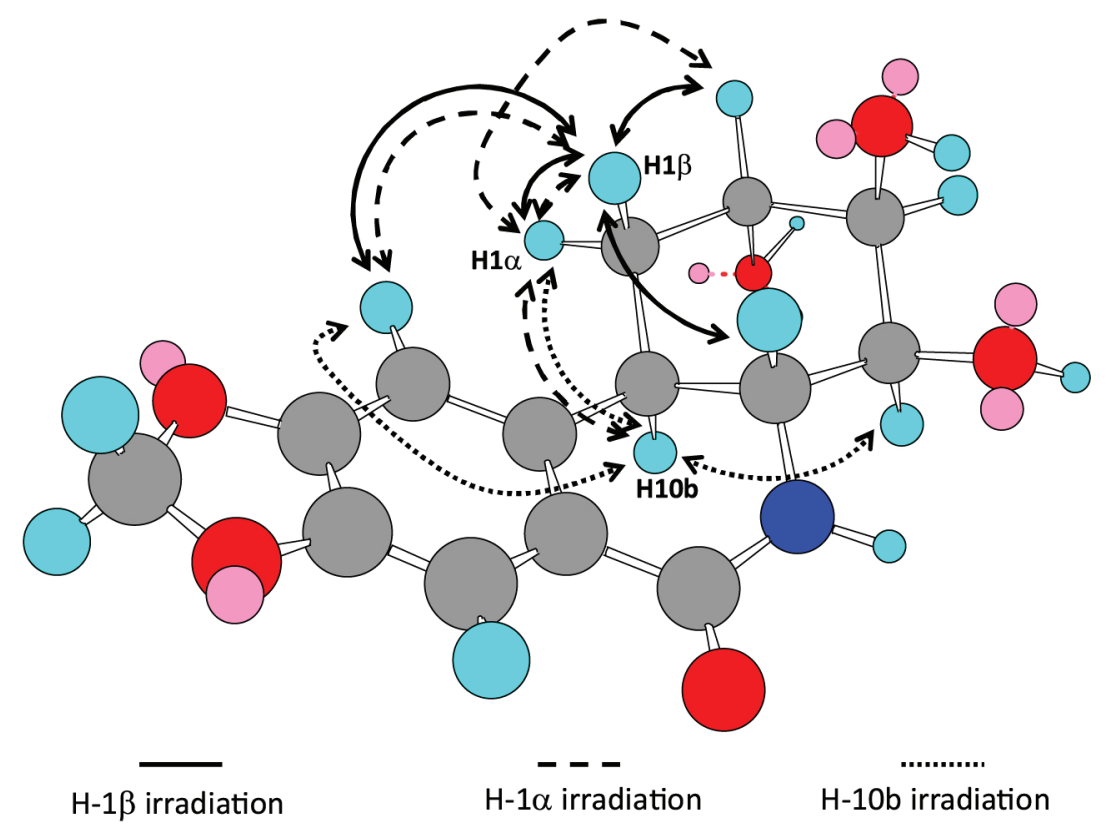

Figure 3. 1D-NOE correlation for compound 2.

Compound 6 was identified as 9- $O$-demethyllycoramine after comparison of its NMR data (Figures S22-S25, SI section) with the literature. This compound was previously obtained from Lycoris radiata (Amaryllidaceae) ${ }^{30}$ and compounds 11 and $\mathbf{1 3}$ were identified as lycorine and pseudolycorine, respectively. These compounds are commonly found in Amaryllidaceae species. ${ }^{21}$ Their NMR data can be seen in Table S1 (SI section).

\section{Cytotoxic activity}

Results of tumor growth inhibition obtained from MTT assay $^{31}$ showed the sensitivity of colorectal (HCT-116) and breast (MCF-7) carcinoma cell lines, as well as of non-tumor retinal pigment epithelium cell line, for 7-deoxi-transdihydronarciclasine (2) and pseudolicorine (13) (Table 4, Figure S28, SI section). The half-maximum inhibitory concentration $\left(\mathrm{IC}_{50}\right)$ of narciclasine derivative (2) for each cell line is comparable to the positive control (doxorubicin), indicating its considerable cytotoxic activity. Compound $\mathbf{1 3}$ is less cytotoxic than compound $\mathbf{2}$; however, it is ten times more selective to HCT-116 cell line in comparison to the non-tumor cell line RPE (Table 4). The high cytotoxicity of compound 2 from Hippeastrum goianum with $\mathrm{IC}_{50}$ varying from 0.15 to $0.2 \mu \mathrm{M}$ is consistent with the cytotoxic potential of Amaryllidaceae isocarbostyrils in general, which generally show $\mathrm{IC}_{50}$ smaller than $1 \mu \mathrm{M}$ against carcinomas, gliomas and menanomas cells. ${ }^{32}$ Compound $\mathbf{2}$, isolated from Hymenocallis littoralis, showed potent cytotoxicity in a panel of cancer cell lines from different origins, including MCF-7, where they found a $\operatorname{IC}_{50}(0.1 \mu \mathrm{M})$ similar to the one obtained herein. ${ }^{33}$ Compound $\mathbf{2}$ is actually consistently less active than narciclasine, that presented $\mathrm{IC}_{50}$ values ranging from 0.01 to $0.09 \mu \mathrm{M}$ against four different cell lines. ${ }^{34}$ Pseudolycorine (13), isolated from another genus from the Amaryllidaceae family (Narcissus tazetta),

Table 4. Mean inhibitory concentration $\left(\mathrm{IC}_{50}\right)$ and confidence interval $(95 \%)$ of the compounds $\mathbf{1}, \mathbf{2}, \mathbf{6}, \mathbf{1 1}, \mathbf{1 3}$ and the positive control doxorubicin in colorectal carcinoma (HCT 116), mammary carcinoma (MCF-7) and non-tumor human retinal pigment epithelium $(\mathrm{RPE})$ cell lines $(\mathrm{mean} \pm \mathrm{SEM})(\mathrm{n}=3)$

\begin{tabular}{|c|c|c|c|c|c|c|}
\hline \multirow[b]{2}{*}{ Compound } & \multicolumn{2}{|c|}{ HCT-116 } & \multicolumn{2}{|c|}{ MCF-7 } & \multicolumn{2}{|c|}{ RPE } \\
\hline & $\mathrm{IC}_{50} / \mu \mathrm{M}$ & $\begin{array}{c}\text { Confidence intervals } \\
95 \%\end{array}$ & $\mathrm{IC}_{50} / \mu \mathrm{M}$ & $\begin{array}{c}\text { Confidence intervals } \\
95 \%\end{array}$ & $\mathrm{IC}_{50} / \mu \mathrm{M}$ & $\begin{array}{c}\text { Confidence intervals } \\
95 \%\end{array}$ \\
\hline 1 & $>50$ & - & $>50$ & - & $>50$ & - \\
\hline 2 & 0.15 & $0.10-0.22$ & 0.2 & $0.1-0.3$ & 0.3 & $0.2-0.6$ \\
\hline 6 & $>50$ & - & $>50$ & - & $>50$ & - \\
\hline 11 & $>50$ & - & $>50$ & - & $>50$ & - \\
\hline 13 & 4.6 & $3.4-6.0$ & 10.6 & 8.9-12.6 & 42.6 & $32.0-56.7$ \\
\hline Doxorubicin & 0.4 & $0.24-0.62$ & 0.6 & $0.4-0.8$ & 1.2 & $0.8-1.6$ \\
\hline
\end{tabular}


has previously shown promising cytotoxicity against two different cervical carcinoma cell lines. ${ }^{35}$ When isolated from $H$. solandriflorum, ${ }^{34}$ compound $\mathbf{1 3}$ showed higher cytotoxicity than observed herein, where the obtained $\mathrm{IC}_{50}$ values against the tumor cell line HCT-116 were 5.4 times higher when compared to the previous work $\left(\mathrm{IC}_{50} 0.85 \mu \mathrm{M}\right)$.

\section{Conclusions}

In summary, thirteen Amaryllidaceae alkaloids were unambiguously identified from the indigenous Brazilian species Hippeastrum goianum by means of GC-MS, 1D/2D-NMR, and VCD methods. For the first time in Amaryllidoideae species (former Amaryllidaceae family) compound $\mathbf{1}$ has been characterized. Compound $\mathbf{1}$ is a representative of a very uncommon five-membered lactone moiety skeleton in Amaryllidoideae plants, which has been very recently accepted as a new subgroup named galasineskeleton. The determination of another representative of the galasine-type skeleton in Amaryllidoideae subfamily is an outstanding finding in terms of chemotaxonomy. Furthermore, the complete and unambiguous NMR data for compound $\mathbf{1}$ along with the determination of its absolute configuration by means of VCD is reported herein. Compound $\mathbf{2}$ is a representative of the cytotoxic skeleton narciclasine-type, an isocarbostyril derivative. The complete and unambiguous assignment of $\mathbf{2}$ using 1D/2D NMR experiments led to the relative configuration of its stereocenters. The use of VCD spectroscopy allowed the determination of its absolute configuration, confirming the typical stereochemistry described in narciclasinetype skeletons from Amaryllidoideae plants. VCD has been successfully applied for stereochemical studies of a tazettine derivative, ${ }^{36}$ but this is the first time VCD spectroscopy is used in narciclasine-type alkaloids. In terms of the cytotoxic activity of $\mathbf{2}$, it has been previous studied against a wide range cancer cell lines, and the observed $\mathrm{IC}_{50}$ values are in the same range $(0.1-0.2 \mu \mathrm{M})$ than the ones described herein, endorsing 2 as a promising anticancer compound. These findings emphasize the great chemical and biological potential of the Amaryllidoideae species.

\section{Supplementary Information}

Supplementary information (NMR, VCD and MS data) are available free of charge at http://jbcs.sbq.org.br as PDF file.

\section{Acknowledgments}

This study was funded by the Coordination of
Superior Level Staff Improvement-Brazil (CAPES)finance code 001, by the National Council of Scientific and Technological Development-CNPq and Foundation of Support to Research and Innovation of Espírito Santo (FAPES Universal No. 80708382/18). We also would like to acknowledge INCTBioNat (CNPq 465637/2014-0 and FAPESP 2014/50926-0), for additional support, NCQPUFES and Programa CYTED (416RT0511). M.H.V. thanks FAPES/CAPES for scholarship and the financial support (76583961/16). J.P.A. is thankful to the FAPES (76192970/16) for a postdoctoral fellowship. A.N.L.B. thank CAPES for a scholarship (No. 88887.313278/2019-00). J.M.B.J. thanks FAPESP and CNPq for funding (grant No. 2014/25222-9 and 431978/2018-2, respectively). L.V.C.L. and L.C.A. thank FAPESP for funding and a scholarship (grants No. 2015/17177-6 and 2018/17595-0, respectively). This research was also supported by resources supplied by the Centre for Scientific Computing (NCC/ GridUNESP) of São Paulo State University (UNESP).

\section{Author Contributions}

M.L. was responsible for investigation; M.H.V. for investigation, writing original draft; J.P.A. for investigation, writing original draft; F.P. for conceptualization; L.C.A. for investigation; L.C.V.L. for conceptualization; A.C.N. for investigation; S.C.C.O. for investigation; J.B. for conceptualization, writing-review and editing; A.N.L.B. for investigation; J.M.B.J. for investigation; W.S.B. for conceptualization, project administration, resources, writing original draft.

\section{References}

1. Judd, W. S.; Campbell, C. S.; Kellogg, E. A.; Stevens, P. F.; Donoghue, D. J.; Plant Systematics: A Phylogenetic Approach, $3^{\text {rd }}$ ed.; Sinauer Associates, Inc.: Sunderland, USA, 2008.

2. de Andrade, J. P.; Pigni, N. B.; Torras-Claveria, L.; Guo, Y.; Berkov, S.; Reyes-Chilpa, R.; Amrani, A. E.; Zuanazzi, J. A. S.; Codina, C.; Viladomat, F.; Bastida, J.; Rev. Latinoam. Quim. 2012, 40, 83 .

3. Silva, A. F. S.; de Andrade, J. P.; Machado, K. R. B.; Rocha, A. B.; Apel, M. A.; Sobral, M. E. G.; Henriques, A. T.; Zuanazzi, J. A. S.; Phytomedicine 2008, 15, 882.

4. da Silva, A. F. S.; de Andrade, J. P.; Bevilaqua, L. R.; de Souza, M. M.; Izquierdo, I.; Henriques, A. T.; Zuanazzi, J. A. S.; Pharmacol., Biochem. Behav. 2006, 85, 148.

5. Pagliosa, L. B.; Monteiro, S. C.; Silva, K. B.; de Andrade, J. P.; Dutilh, J.; Bastida, J.; Cammsrota, M.; Zuanazzi, J. A. S.; Phytomedicine 2010, 17, 698.

6. Kornienko, A.; Evidente, A.; Chem. Rev. 2008, 108, 1982. 
7. Efferth, T.; Saeed, M. E. M.; Kadioglu, O.; Seo, E. J.; Shirooie, S.; Mbaveng, A. T.; Nabavi, S. M.; Kuete, V.; Biotechnol. Adv. 2020, 38, 107342.

8. Dutta, S.; Mahalanobish, S.; Saha, S.; Ghosh, S.; Sil, P. C.; Food Chem. Toxicol. 2019, 128, 240.

9. Davidson, E. K.; Brimble, M. A.; Curr. Opin. Chem. Biol. 2019 , 52,1 .

10. http://floradobrasil.jbrj.gov.br/jabot/floradobrasil/FB26367 accessed in June 2020.

11. Costa, G. G. P.; Silva, C. A. G.; Gomes, J. V. D.; Torres, A. G.; Santos, I. R. I.; de Almeida, F. T. C.; Luiz, C. W. F.; Simeoni, A.; Silveira, D.; Gomes-Copeland, K. K. P.; Rev. Bras. Farmacogn. 2019, 29, 262.

12. AMDIS Automated Mass Spectral Deconvolution and Identification System, v. 2.65; MA, USA, 2008.

13. GraphPad Prism v. 8.0; GraphPad Software, San Diego, USA, 2018.

14. HyperChem 8.0.10; Hypercube, Inc., Gainesville, USA, 2011.

15. Frisch, M. J.; Trucks, G. W.; Schlegel, H. B.; Scuseria, G. E.; Robb, M. A.; Cheeseman, J. R.; Scalmani, G.; Barone, V.; Mennucci, B.; Petersson, G. A.; Nakatsuji, H.; Caricato, M.; Li, X.; Hratchian, H. P.; Izmaylov, A. F.; Bloino, J.; Zheng, G.; Sonnenberg, J. L.; Hada, M.; Ehara, M.; Toyota, K.; Fukuda, R.; Hasegawa, J.; Ishida, M.; Nakajima, T.; Honda, Y.; Kitao, O.; Nakai, H.; Vreven, T.; Montgomery Jr., J. A.; Peralta, J. E.; Ogliaro, F.; Bearpark, M.; Heyd, J. J.; Brothers, E.; Kudin, K. N.; Staroverov, V. N.; Kobayashi, R.; Normand, J.; Raghavachari, K.; Rendell, A.; Burant, J. C.; Iyengar, S. S.; Tomasi, J.; Cossi, M.; Rega, N.; Millam, J. M.; Klene, M.; Knox, J. E.; Cross, J. B.; Bakken, V.; Adamo, C.; Jaramillo, J.; Gomperts, R.; Stratmann, R. E.; Yazyev, O.; Austin, A. J.; Cammi, R.; Pomelli, C.; Ochterski, J. W.; Martin, R. L.; Morokuma, K.; Zakrzewski, V. G.; Voth, G. A.; Salvador, P.; Dannenberg, J. J.; Dapprich, S.; Daniels, A. D.; Farkas, Ö.; Foresman, J. B.; Ortiz, J. V.; Cioslowski, J.; Fox, D. J.; Gaussian 09, Revision A.02; Gaussian: Wallingford, CT, 2009.

16. Origin 8.0; OriginLab, Northampton, USA, 2007.

17. Wang, Y. H.; Zhang, Z. K.; Yang, F. M.; Sun, Q. Y.; He, H. P.; Di, Y. T.; Mu, S. Z.; Lu, Y.; Chang, Y.; Zheng, Q. T.; Ding, M.; Dong, J. H.; Hao, X. J.; J. Nat. Prod. 2007, 70, 1458.

18. Cimmino, A.; Masi, M.; Evidente, M.; Superchi, S.; Evidente, A.; Chirality 2017, 29, 486.

19. Pettit, G. R.; Pettit III, G. R.; Backhaus, R. A.; Boyd, M. R.;
Meerow, A. W.; J. Nat. Prod. 1993, 56, 1682.

20. Berkov, S.; Bastida, J.; Viladomat, F.; Codina, C.; Talanta 2011, $83,1455$.

21. Berkov, S.; Osorio, E.; Viladomat, F.; Bastida, J. In The Alkaloids: Chemistry and Biology, vol. 83; Elsevier: Cambridge, 2020, p. 113.

22. Schnoes, H. K.; Smith, D. H.; Burlingame, A. L.; Jeffs, P. W.; Dopke, W.; Tetrahedron 1962, 24, 2825.

23. Jeffs, P. W.; Abou-Donia, A.; Campau, D.; Staiger, D.; J. Org. Chem. 1985, 50, 1732.

24. Latvala, A.; Önür, M. A.; Gözler, T.; Linden A.; Kivçak, B.; Hesse, M.; Phytochemistry 1995, 39, 1229.

25. Ghosal, S.; Saini, K. S.; Razdan, S.; Phytochemistry 1985, 24 , 2141.

26. Pigni, N. B.; Berkov, S.; Elamrani, A.; Benaissa, M.; Viladomat, F.; Codina, C.; Bastida, J.; Molecules 2010, 15, 7083.

27. Bastida, J.; Berkov, S.; Torras, L.; Pigni, N. B.; de Andrade, J. P.; Martínez, V.; Codina, C.; Viladomat, F.; Recent Adv. Pharm. Sci. 2011, 65.

28. Weirich, L.; Merten, C.; Phys. Chem. Chem. Phys. 2019, 21, 13494.

29. Pagning, A. L. N.; Tamokou, J. D.; Khan, M. L.; Ali, M. I.; Hameed, A.; Ngnokam, D.; Tapondjou, L. A.; Kuiate, J. R.; Ali, M. S.; S. Afr. J. Bot. 2016, 102, 166.

30. Kobayashi, S.; Yuasa, K.; Imakura, Y.; Kihara, M.; Shingu, T.; Chem. Pharm. Bull. 1980, 28, 3433.

31. Mosmann, T.; J. Immunol. Methods 1983, 65, 55.

32. van Goietsenoven, G.; Mathieu, V.; Lefranc, F.; Kornienko, A.; Evidente, A.; Kiss, R.; Med. Res. Rev. 2013, 33, 439.

33. Pettit, G. R.; Eastham, S. A.; Melody, N.; Orr, B.; Herald, D. L.; McGregor, J.; Knight, J. C.; Doubek, D. L.; Pettit III, G. R.; Garner, L. C.; Bell, J. A.; J. Nat. Prod. 2006, 69, 7.

34. Carvalho, K. R.; Silva, A. B.; Torres, M. C. M.; Pinto, F. C. L.; Guimarães, L. A.; Rocha, D. D.; Silveira, E. R.; Costa-Lotufo, L. V.; Braz-Filho, R.; Pessoa, O. D. L.; J. Braz. Chem. Soc. 2015, 26, 1976.

35. Katoch, D.; Kumar, D.; Padwad, Y. S.; Singh, B.; Sharma, U.; Nat. Prod. Res. 2019, DOI 10.1080/14786419.2019.1574785.

36. Vergura, S.; Santoro, E.; Masi, M.; Evidente, A.; Scafato, P.; Superchi, S.; Mazzeo, G.; Longhi, G.; Abbate, S.; Fitoterapia 2018, 129, 78.
Submitted: March 11, 2020

Published online: June 17, 2020 